\title{
開水路サイドキャビティ領域における堆積高が 乱流構造に与える影響
}

\author{
HYDRODYNAMIC EFEFCTS OF BOTTOM SEDIMENTATION ON \\ TURBULENCE STRUCTURE WITHIN SIDE-CAVITY ZONE IN OPEN-CHANNEL
}

\author{
山上路生 1 ・金子泰洸ポール 2 ・崎谷健太 ${ }^{2} ・$ 藤本雄大 ${ }^{2}$ ・戸田圭一 3 \\ Michio SANJOU, Taiko-Paul KANEKO, Kenta SAKITANI, Yuta FUJIMOTO and Keiichi TODA \\ 1正会員 博(工) 京都大学准教授 工学研究科社会基盤工学専攻（干615-8540 京都市西京区京都大学桂） \\ 2学生員 京都大学大学院修士課程 工学研究科社会基盤工学専攻（同上） \\ 3正会員 $\mathrm{PhD}$ 京都大学教授 工学研究科社会基盤工学専攻（同上）
}

\begin{abstract}
A lot of sediments are often captured in the dead water zone such as an embayment. It is well known that a velocity difference between the main-channel and the side cavity induces a shear instability. Additionally, large-scale horizontal circulations are also formed in the whole cavity region. These multiscale turbulent vortices contribute to mass transfer through a mainstream / embayment boundary and a local sedimentation in the cavity. When the bed configuration varies in space and time, they give striking impacts on hydraulic characteristics. However, the relation between the local sedimentation and the distributions of mean velocity and turbulence is still poorly understood. In the present study, velocity measurements are conducted in a smooth bottom condition and movable one in order to consider how the turbulence structure and exchange properties changes.
\end{abstract}

Key Words : side cavity, turbulence, open-channel flow and sedimentation

\section{1. はじめに}

平成9年の河川法改正以後, 河道の多様性が求められ ている. そのような社会的要請の中で多くの人工ワンド が設置されてきた. ワンドは主流と隔離された領域であ り，特有の生態空間を形成するとともに貴重な親水空間 を提供する. 一方で，よどみによる水質の悪化や洪水時 の激流による土砂の堆積・洗掘は深刻である.

中川ら ${ }^{1)}$, Uijttewaalら ${ }^{2)}$ および著者らのグループ3)が指 摘しているように開水路側岸の止水域における循環流の 構造は，シンプルな矩形領域であっても，その開口部の 遮蔽率やアスペクト比（開口部長／奥行）によって大き く変化する. 特にアスペクト比が大きくなると Secondary Gyreとよばれる副循環流が生成し，ワンド内 物質を滞留させる．また高水敷上まで汇濫しワンドを越 流する状態では，冨永ら ${ }^{4}$ が報告しているように，流れ は3次元的になり水平循環流と横断軸をもつせん断渦の 相互作用が顕著となる.

実河川に設置された人工ワンドの堆積についても多く

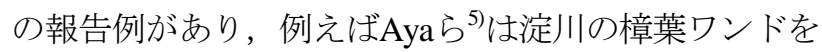
対象に, 洪水による河床地形変化や粒度特性に関する データを収集し, 流速計測に基づく土砂堆積のメカニズ ムについて検討している. また冨永・榊 $)^{6}$ は矢田川の人 エワンドの現地観測を中心に，低水路／ワンド境界部付
近においては，拡幅による流速低下が開口部の閉塞や埋 没を誘発することを示している. 堆積を支配する水理要 因は多々考えられるが，ワンドを構成する上下流端の水 制の低水路への張り出し角度がその一つとされている. 特に木曽川のワンド群は, 位置ごとに堆積状況が大きく 異なるがこれも張り出し角度の差異によるものと考えら

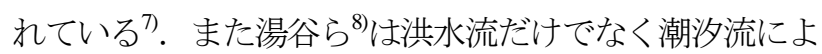
る人工ワンドへの土砂流入特性を研究し, 周囲の植生群 落によって土砂堆積が軽減されたことを報告している.

このように人エワンドの堆積・埋没についてはその対応 策の構築が急務であるが，同時に流域ごとのバックグラ ウンドに依存するため一般的な解決法を見出すことは困 難である. そのため基礎研究と現地計測の積み重ねを根 気よく続ける必要がある。

基礎研究としては, 複数のグループが実験室水路にお ける正方形ワンドの土砂堆積特性を検討している. 例え ば山坂9)の結果では, 堆積高ピークがワンドの中心に現 れるが，この理由を循環流の圧力勾配と遠心力のバラン スから説明している．また日下部ら ${ }^{10}$ は円柱によるモデ ル植生をワンド内に設置して, その有無と流入土砂量の 関係を論じている，ただしこの両グループの堆積特性を 比較しても一致しているとは言い難く, ワンド内堆積に は，流速や水深条件だけでなく給砂の方法など実験手法 に依存する可能性も大きい. 
表-1 実験条件

\begin{tabular}{|c|c|c|c|c|c|c|c|c|c|}
\hline ケース & 路床 & $U_{m}(\mathrm{~cm} / \mathrm{s})$ & $H(\mathrm{~cm})$ & $B(\mathrm{~cm})$ & $B_{w}(\mathrm{~cm})$ & $L_{w}(\mathrm{~cm})$ & $L_{w} / B_{w}$ & 勾配 & $F_{r}$ \\
\hline U36A1000F & \multirow{3}{*}{ 固定床 } & \multirow{6}{*}{36} & \multirow{6}{*}{5.3} & \multirow{6}{*}{120} & 30 & \multirow{6}{*}{30} & 1 & \multirow{6}{*}{$1 / 10000$} & \multirow{6}{*}{0.5} \\
\hline U36A2000F & & & & & 15 & & 2 & & \\
\hline U36A3000F & & & & & 10 & & 3 & & \\
\hline U36A1000M & \multirow{3}{*}{ 移動床 } & & & & 30 & & 1 & & \\
\hline U36A2000M & & & & & 15 & & 2 & & \\
\hline U36A3000M & & & & & 10 & & 3 & & \\
\hline
\end{tabular}

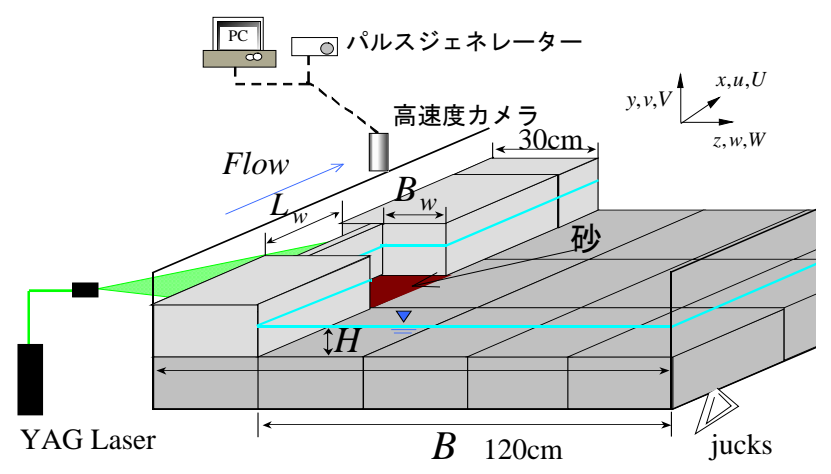

図-1＼cjkstart実験装置と座標系

ワンドの堆積状況は主に，主流からの土砂供給，止水 域の循環流による洗掘・堆積および主流への流出に依存 する複雑な現象である. 本研究は2，3点目の物理機構を 解明すべく, 主流からの土砂流入がない条件に焦点を 絞ってワンド内の路床変動特性を計測する.さらに路床 境界面の変化が流れ場や乱流構造に及ぼす影響を解明す る. 特にSecondary Gyre の発生特性を明らかにするため にアスペクト比も系統変化させる. 特に低水路／高水敷 の境界部に発生するレイノルズ応力は，運動量交換や流 水抵抗と密接するから，この分布特性を滑面と移動床の 双方から比較・検討する.

\section{2. 実験方法}

図-1に本移動床実験に用いた装置図を示す。乱流計測 は, 全長 $9 \mathrm{~m}$, 全幅 $150 \mathrm{~cm} の$ 循環式大型直線水路で行った.
水路の両外脇にレールを設け，水路を横断するように移 動台車を設置してある，底面はステンレス製であり，壁 面は強化ガラス製である. 最上流部には整流のためのハ 二カムが設置してある. 図に示すように，水路に中空の アクリル製のボックス（全長 $60 \mathrm{~cm}$, 高さ $20 \mathrm{~cm}$, 幅 $30 \mathrm{~cm}$ ）を5列敷き詰めて，さらに水路の左岸側に1列だ け重小て並べ，上流から約6 $\mathrm{m}$ の位置に隙間（30× $30 \mathrm{~cm}$ ）を設けることでサイドキャビテイ領域，すなわ ち長方形ワンドを再現した。 しきり板（全長 $30 \mathrm{~cm}$, 高 さ20cm，幅 $5 \mathrm{~cm} ）$ をキビティ内に挿入することで，ア スペクト比を変化させた. またアクリルボックスの浮遊 を防ぐために内部に錘としてレンガブロックを入れた. 本計測ではPIV計測の際に，トレーサーとして粒形 $100 \mu$ $\mathrm{m}$, 比重1.02のナイロン11粒子をエタノールに浸しフ ロッキングしない中立浮遊粒子とし，十分な量を水路中 に循環させている.

後述するように本研究では固定床とキャビティ内のみ 移動床の2種類の路床条件を扱う。移動床ではキャビ ティ領域の底面ボックスを取り除き，その部分の空隙に 砂を設置するためのボックス（全長 $30 \mathrm{~cm}$, 幅 $30 \mathrm{~cm}$, 高 さ60cm）を設置した。 ボックスは主流側の面だけ仕切 りがない構造であり，ボックス内に主流部の底面高さま で砂を敷き詰めることによって移動床ワンドを再現した. 本計測で用いた砂は6号珪砂（粒径0.2〜0.4mm）であり， その粒径は半水深以上の過度な堆積が発生しないように 決定した. (a) $L_{w} / B_{w}=1.0$

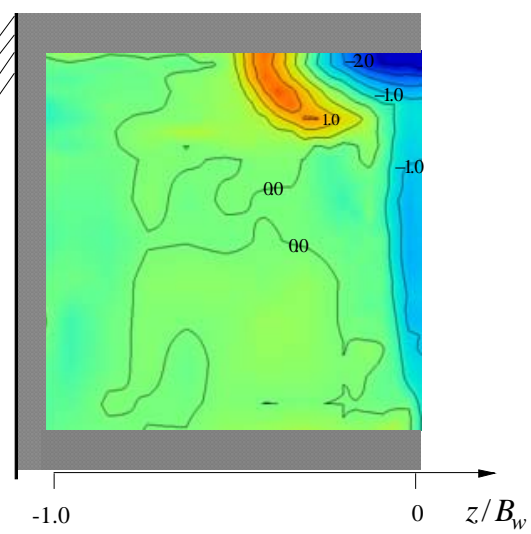

(b) $L_{w} / B_{w}=2$

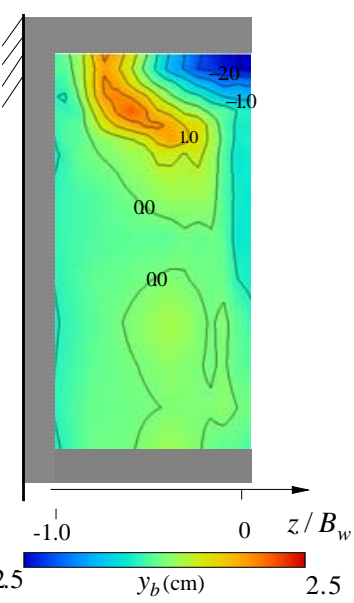

(c) $L_{w} / B_{w}=3$

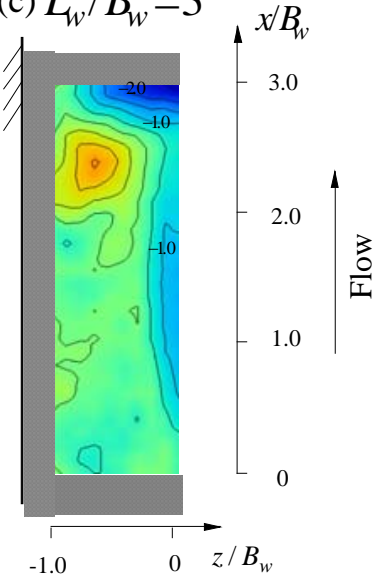

図-2 移動床ケースにおけるキャビティ路床高の分布 
(a) 移動床

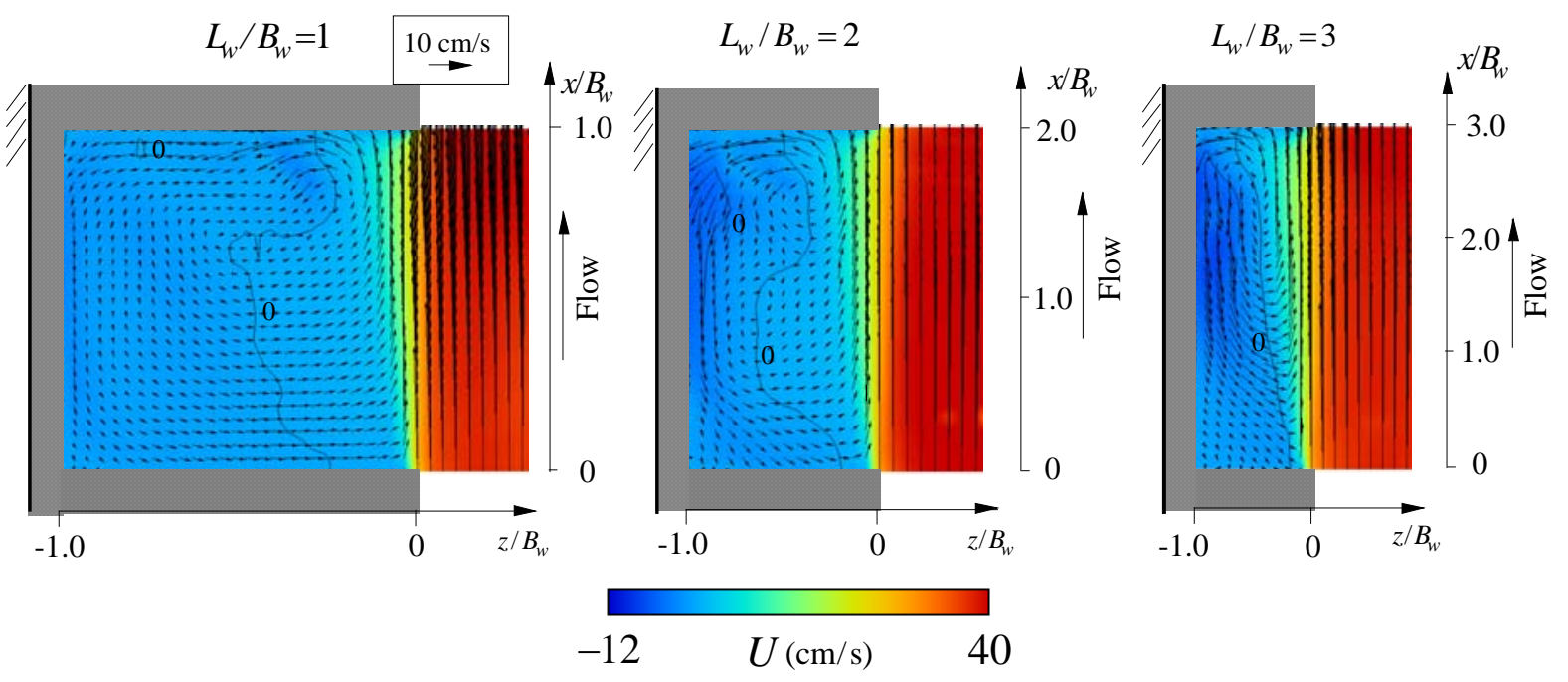

(b) 滑面

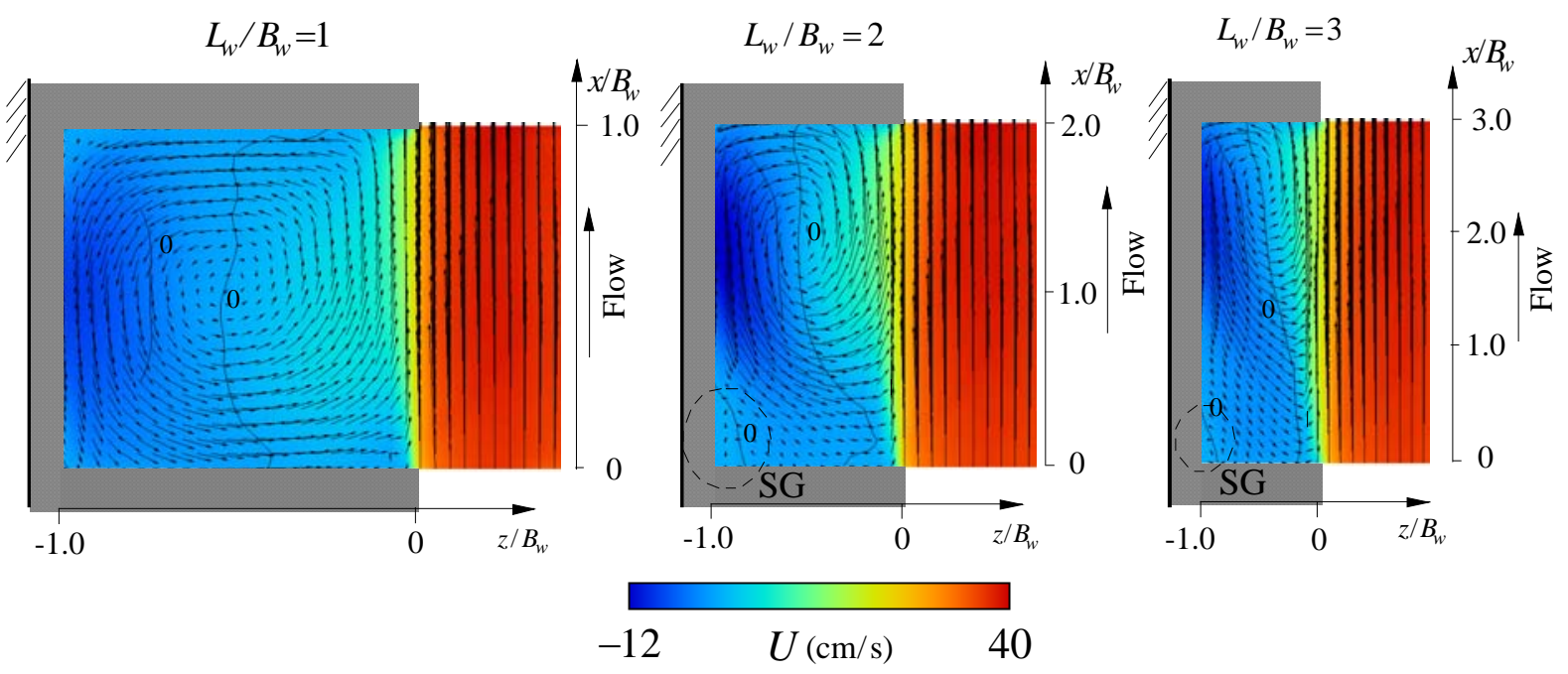

図-3 時間平均流速ベクトル分布

表-1に水理条件を示寸. 断面平均流速 $U_{m}=36 \mathrm{~cm} / \mathrm{s}$, 主水路幅 $B=120 \mathrm{~cm}$, キャビティ幅 $B_{w}=10,15,30 \mathrm{~cm}$, ワンド長さ $L_{w}=30 \mathrm{~cm}$ である。アスペクト比は $L_{w} / B_{w}=1 ， 2 ， 3 の 3$ パターンとした. 計測手順は次の 通りである. ボックス内に主流部の底面高さまで珪砂を 敷き詰めた後, ワンド/主流の境界部にスプリッタープ レートを設置した状態で水路に水を流す。これは，通水 直後に河床の砂が移動することを防ぐためである，主流 部の流れが安定した後にスプリッタープレートを取り除 き，この瞬間を通水開始時刻とした。この時刻から2時 間後に水平面のPIV 計測を行った。計測面は半水深 $(y / H=0.47 ）$ である. PIV計測後に通水を止めて, ト ラバース付きの移動台車（ $x-z$ - 2 方向）にポイントゲー ジを設置して路床高 $(y$ 方向 $)$ の計測を行った. トラバー スは $x, y$ 方向には $0.1 \mathrm{~mm}, z$ 方向には $0.01 \mathrm{~mm} の$ 分解能が あり, $x, y$ 方向のトラバースで計測位置を, $z$ 方向はポ イントゲージを用いて河床高さを決定した.

固定床の場合は底面極近傍を除いて鉛直方向に水平循
環流の構造が大きく変化しないことがわかっている3゙が， 移動床の場合は平坦路床にならず3次元性が強いため, 一つの代表計測高さで現象を評価できない，そのためこ こでは固定床と移動床の比較を重視して半水深高さの現 象に限定して以後の議論を進めるものとする.

\section{3. 実験結果と考察}

\section{（1） 路床堆積高の特性}

図-2はキャビティ内の路床堆積高 $y_{b}$ の分布をコン ターで表したものである. 正值が堆積を負值が洗掘を表 す．これから，いずれのケースにおいても主流とキャビ ティの境界部に沿って洗掘が発生するが，キャビティ下 流端で特に大きな洗掘が確認できる.さらにそのサイド に大きな堆積がみられる．また境界部とキャビティ下流 端で観察される洗掘・堆積以外は路床形状に顕著な変化

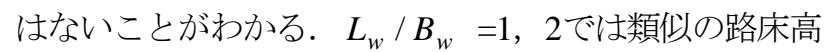




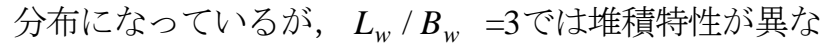
る.これは, $L_{w} / B_{w}=3 の$ 場合は堆積の位置がワンド側 壁側まで達するため，側壁の影響がこのような差異を生 んだものと予想される. 洗掘の様子は他のケースと比べ て大きな違いはなく，これらのことからキャビティ幅に 関係なく同じような洗掘・堆積のメカニズムが存在する と推察される. 目視で流れ場を観察すると, 主流とキャ ビティ境界部とキャビティ下流端では周期的で間欠的な 砂の巻き上がりがみられた．境界部では周期的な大規模 せん断渦が発生しており, ワンド下流側ではその大規模 な渦が強い流れ込みとなって周期的に流入することが確 認できた. 著者ら゙は（滑面状態の長方形型キャビティ 流れにおける鉛直断面の平均流速べクトル分布より, キャビティ下流端境界近傍（大きな洗掘があるところ） で下降流が生じることを明らかにしている。したがって, 周期的な大規模せん断渦と下降流が洗掘促進の主要因で あるといえる。

\section{（2） 水平面の時間平均流速ベクトル分布}

図-3は移動床と固定床滑面における時間平均流速 $(U, W)$ をベクトル表示で比較したものである. 計測断面 は半水深（ $y / H=0.47 ）$ である. コンターは主流方向 流速Uで，図中には $U=0$ の等值線を記入した．これを みると，移動床と滑面固定床ケースでは流れ構造が大き く異なることがわかる．特に $L_{w} / B_{w}=1 ， 2$ では顕著と なっている. 路床形状分布で考察したようにキャビティ 下流側には大きな洗掘と堆積がみられるため，その凹凸 が流れに対する抵抗となって流れ構造に影響を与えると 考えられる.

$L_{w} / B_{w}=1$ ではPrimary Gyre (PG)の中心位置がワンド 下流側に移動しており，下流側が小さく上流側が大きく なった棈円形の循環流構造になっていることがわかる. またワンド下流端近傍で流れ構造が複雑になっており, これは局所堆積部に衝突した流体塊が半水深 （y/H=0.47）での流れに影響を与えるためと思われ る. 堆積砂がキャビティ下流端から主流方向へ向かって 弧を描いたような形状になるため, 平均流速べクトルで 見たときに反時計回りに回転しているようにみえる.ま たキャビティ側壁近傍にみられる逆流が小さくなること がわかる。

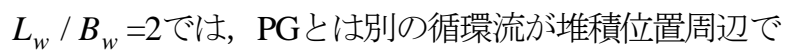
発生する. $L_{w} / B_{w}=1$ と同様に堆積が弧形状になるた め, このような循環流構造となるものと推察される.

PGは渦中心位置が滑面ケースと比べて上流側かつキャ ビティ側壁側によるが，これは堆積箇所で生じた循環流 によって上流側に輸送されるためと考えられる.さらに 滑面のケースでは確認できるSGがみられない。これは

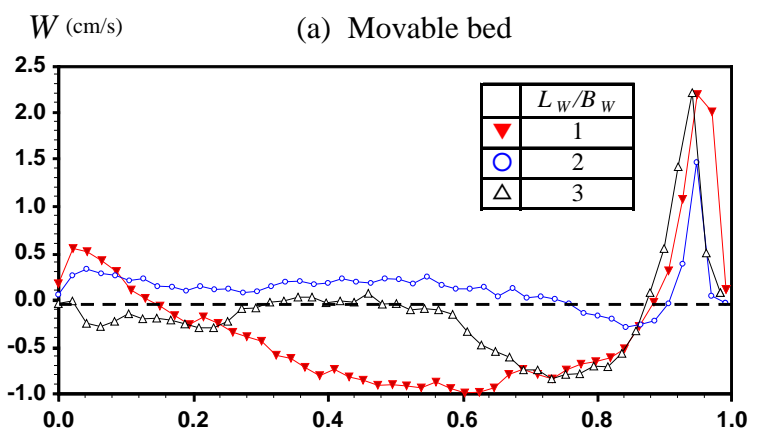

(b) Fixed bed

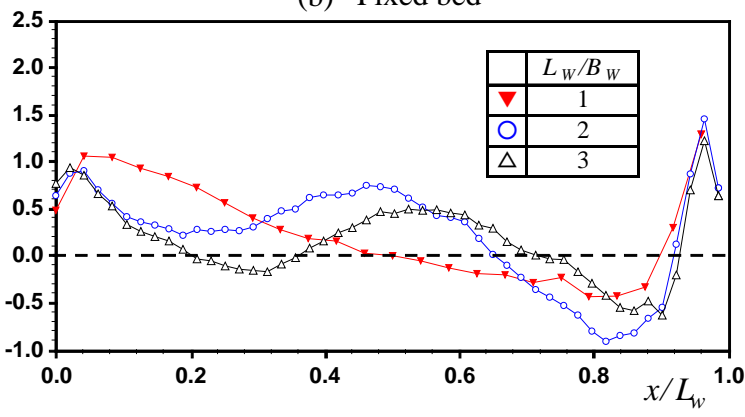

図-4 低水路とキャビティ境界における 時間平均横断方向流速の主流方向分布

上流側にPGが移動したことによってSGの形成スペース が確保されないためと思われる. また $L_{w} / B_{w}=1$ と同様 にワンド側壁側逆流の流速は小さくなる.

一方で, $L_{w} / B_{w}=3$ では $L_{w} / B_{w}=1,2$ と比べて, 路 床条件による流れ構造に大きな変化はない，循環流は PGのみで大きさ, 中心位置ともにほとんど変化しない これは $L_{w} / B_{w}=3$ のースでは堆積の高さが他のケース と比べて若干低くなることと, 堆積の位置及び形状が関 係するものと思われる．堆積がキャビティ下流端及び側 壁に近接せずキャビティ内に位置するため, $L_{w} / B_{w}=3$ ケースでは流速が大きくなる壁側の流れ、

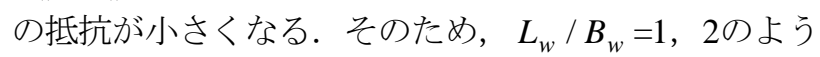
にキャビティ内への流入直後に堆積部に衝突するケース よりは, 堆積が流れ構造に与える影響が小さくなるもの と考えられる.

\section{（3）境界部における流出入状況の考察}

図-4に移動床と固定床の低水路／キャビティ境界部に おける横断方向平均流速Wの主流方向変化を示寸. 移動 床と固定床では境界部の横断方向Wに大きな違いがみら れる.まず固定床ではワンド上流部の大部分の区間で流 出となる一方で, $L_{w} / B_{w}=2$ 以外については移動床では 同じ区間のほとんどキャビティ内への流入となっている. また移動床は境界部全体を通して流入が卓越する。流入 量は, $L_{w} / B_{w}=3$ より 1 の方が大きい. $L_{w} / B_{w}=2$ の移 動床は他と比べて流出も多く違った様相を呈する. 固定 

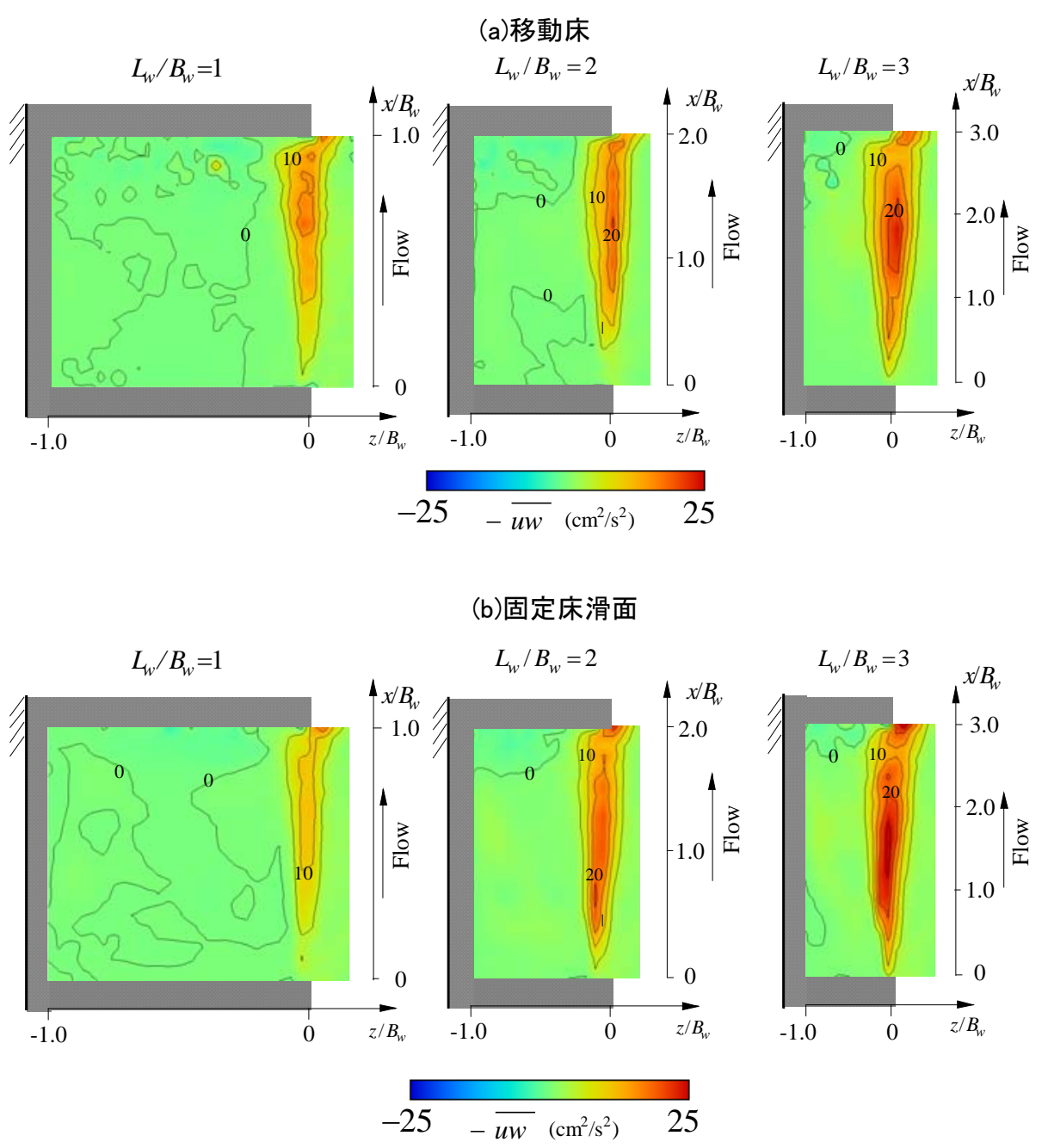

図-5 レイノルズ応力分布

床について注目寸ると, 流出がピークとなる位置はアス ペクト比が大きいほど下流側に移動する，一方このよう な傾向は移動床にはみられない.

同一アスペクト比において路床条件を比較すると， $L_{w} / B_{w}=1$ では移動床で流入が多いのに対して固定床で 流出が多くなる． $L_{w} / B_{w}=2$ は, 移動床ではほとんどの 領域でコンスタントに流出する特性を有することに対し て固定床は上流部で大きく流出し下流部で流入する特徴 的な様相を呈する. $L_{w} / B_{w}=3$ では基本分布形状は類似 するが移動床の方が全体的に流入が多い. 傾向が類似す るのは全体の流れ構造も固定床と移動床であまり変わら ないためであると考えられる.

ただし，いずれの結果についても流入と流出の収支は ゼロにはなっておらず，あくまで半水深位置における考 察であることに留意する必要がある. 特に移動床ケース では高い3次元性が現れるため, 主流とキャビティの輸 送現象を正確に評価寸るためには，境界面 $(x-y)$ 全体 におけるWの分布を考えなければならない. またWの主 流方向変化は大きく, この計測精度についても引き続き 検証する必要がある.

\section{（4） レイノルズ応力の分布}

図-5は移動床と固定床滑面におけるレイノルズ応力 - $\overline{u w}$ のコンター分布を比較したものである. 計測断面 は半水深 $(y / H=0.47)$ である. 移動床および滑面の 双方で, レイノルズ応力の最大值は $L_{w} / B_{w}$ の増加に対 応して大きくなる. 定量的に比較すると, $L_{w} / B_{w}=1$ で

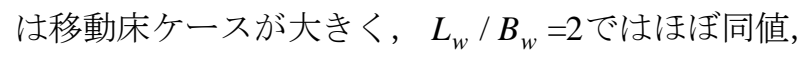
$L_{w} / B_{w}=3$ では滑面ケースが大きいことがわかる.

一般にレイノルズ応力は低速流体と高速流体が乱流混 合することによって生じる運動量フラックスの時間平均 值である.すなわちレイノルズ応力は主流部とキャビ ティ間の運動量交換効率と意味する.また主流部とキャ ビティの境界部における主流速の横断方向勾配が大きい ほどレイノルズ応力が増大する. 図-6に $x / L_{w}=0.5$ に おける主流速の横断分布を比較する. $L_{w} / B_{w}=1,2 て ゙$ は, 移動床のケースでこの流速勾配が増大しており，レ イノルズ応力の生成を促進する.レイノルズ応力の最大 值は $L_{w} / B_{w}=1$ では移動床のケースで大きいが,

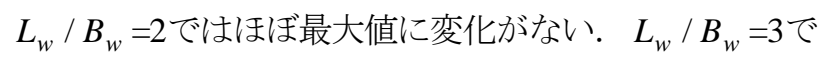
は流速勾配には大きな変化がないが，逆にレイノルズ応 力は移動床のケースが小さくなっている.これらのこと 

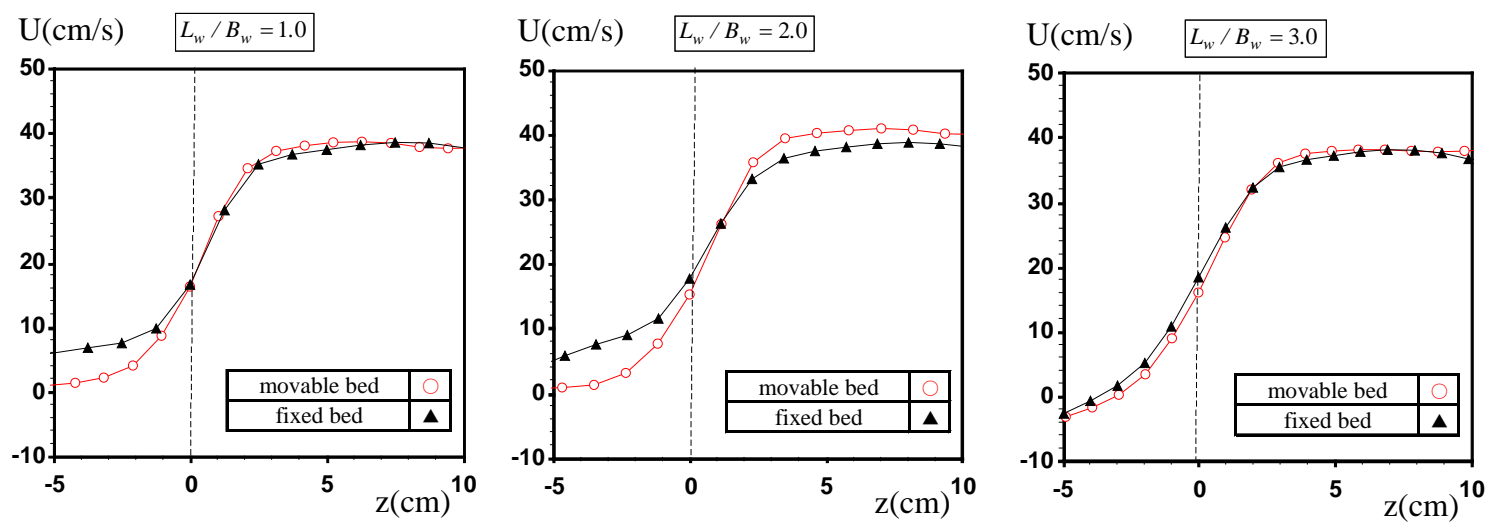

図-6 主流速の横断方向分布の比較 $\left(x / L_{w}=0.5\right)$

から，境界部のレイノルズ応力が一般の混合層のように 単純に流速勾配によってのみ決定されるのではなく, キャビティの循環流構造やキャビティから主流一の流出 機構によっても複雑に影響を受けることが理解できる.

\section{（5）流出土砂量の考察}

最後にサイドキャビティから主流への土砂流出を比較 する. 流出量は通水前後の路床高さの差より求めた. 図-7にキャビティ容積で除した無次元流出土砂量 $\Delta V_{*}$ を 示す．これより全てのアスペクト比において，土砂は流

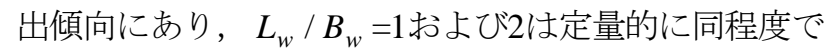
あるが， $L_{w} / B_{w}=3 て ゙ は$ 他の 2 ケースの5倍も大きい.

図-7に示寸ように $L_{w} / B_{w}=3$ のレイノズ応力の分布は 固定床および移動床のいずれにおいても他ケースよりも 大きく，境界部のせん断渦によって低水路側への土砂輸 送が促進されたものと考えられる。

\section{4. おわりに}

本研究では，開水路流れにおけるサイドキャビティ内 のみに珪砂を敷き詰めた移動床条件で乱流計測を行い， 路床形状分布がキャビティ内の循環流特性や乱流構造に 与える影響を考察した. アスペクト比によって堆積形状 に差異が生じた。 また土砂堆積は循環流構造, レイノル ズ応力分布および，主流とキャビティの運動量交換特性 を大きく変化させることがわかった.

謝辞 : 本研究を遂行するにあたり, 京都大学大学院工学 研究科の池内三津喜氏 (現JR西日本) には計測やデータ解 析に多大な協力を頂いた。ここに謝意を表する.

\section{参考文献}

1) 中川研造, 河原能久, 友近文志 : ワンド内の流れの水理特性 に関する実験的研究, 水工学論文集, 第39巻, pp.595-600, 1995.

2) Uijttewaal, W.S.J., D. Lehmann, A.van Mazijk : Exchange processes between a river and its groyne fields: Model experiments, J.H.E, ASCE, 1273(11), pp.928-936, 2001.

3) Sanjou, M., Akimoto, T. and Okamoto, T.: Three-dimensional
$\Delta V_{*}$

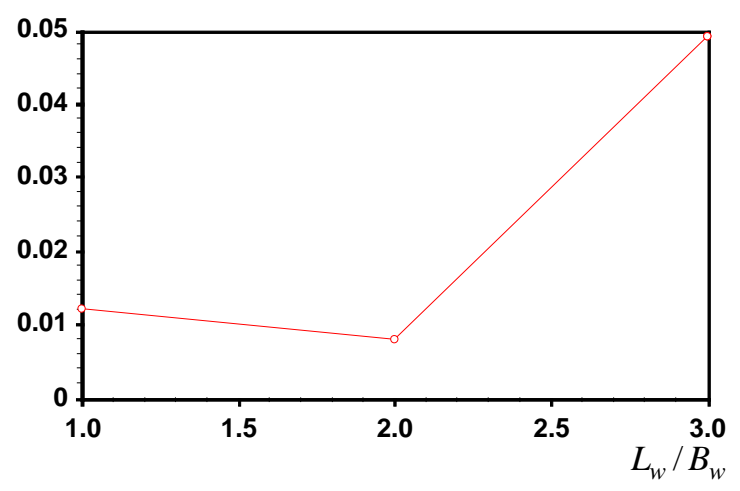

図-7 流出砂量とアスペクト比の関係

turbulence structure of rectangular side-cavity zone in open-channel stream, Int. J. of River Basin Management, IAHR, Vol.10, No.4, pp.293-305, 2012.

4) 冨永晃宏, 鄭載勲, 阪巻実佳, 複断面開水路高水敷に設けら れた凹部の流れ構造, 応用力学論文集, vol.8, pp.883-891, 2005.

5) Aya, S., Nakanishi, F., Satoh, T. and Enoki, M.: Development of the Kuzuha Embayment, the Yodo River, Advances in River Sediment Research, Fukuoka et al.(eds.), pp.1675-1683, 2013.

6) 富永晃宏, 榊卓也 : 砂礫床河川に設置された人工わんど周辺 の河床変動, 水工学論文集, 第54巻, pp.793-798, 2010.

7) 木村一郎, 北村忠紀, 熟見哲也, 武田誠, 鬼束幸樹, 床建冶 朗, 大塚康司 : 木曽川干潮域に設置された水制群周辺のワン ド形成過程と河川環境に関する共同研究，河川技術論文集， 第8巻, pp.365-370, 2002.

8) 湯谷賢太郎, 内田哲夫，佐々木寧，田中規夫 : 潮汐流および 洪水流による人工ワンドへの土砂流入と環境への影響, 水工 学論文集, 第52巻, pp.697-702, 2008.

9) 山坂昌成 : ワンド内の流れと土砂堆積に関する実験, 土木学 会第52回年次学術講演会, pp.496-497, 1997.

10）日下部重幸，辻本剛三，道上正規，檜谷治，藤田正治：人 工ワンド近傍の流れと土砂流入, 平成13年度砂防学会講演 論文集, pI27, 2001.

11）池田駿介, 吉池智明, 杉本高 : 不透過水制群を有する流れ の構造に関する実験的研究, 水工学論文集, 第43巻, pp.281286, 1999.

(2013.9.30受付) 